\title{
İlköğretimde artırılmış gerçeklik destekli disiplinler arası bir öğretim uygulaması
}

\author{
Filiz DÍKKARTIN ÖVEZ ${ }^{1, *}$, Burcu SEZGINSOY ŞEKER ${ }^{2}$ \\ ${ }^{1}$ Ballkesir Üniversitesi, Necatibey Eğitim Fakültesi, Matematik ve Fen Bilimleri Eğitimi Bölümü, \\ Ballkesir, Türkiye \\ ${ }^{2}$ Ballkesir Üniversitesi, Necatibey Eğitim Fakültesi, Temel Eğitim Bölümü, Balıkesir, Türkiye
}

Geliş Tarihi (Received Date): 14.09.2021

Kabul Tarihi (Accepted Date): 28.10.2021

\section{$\ddot{O} \mathbf{z}$}

Bu çalışmanın amacı, disiplinler arası bakış açısı esas alınarak geliştirilen artırılmış gerçeklik $(A G)$ destekli materyallerin uygulamasına yönelik etkinlikler tasarlanmak ve yürütülen eğitimin öğrencilerin başart, materyal motivasyonlarına, tutumlarına ve görüşlerine etkisini incelemektir. Bu amaç doğrultusunda ilkögretim sosyal bilgiler ve matematik dersi ögretim programları kapsamında belirlenen öğrenme kazanımları bütünleştirilerek AG destekli materyallerin uygulaması ve etkinlikler düzenlenmiştir. Araştırma amaçlı örnekleme yöntemlerinden ölçüt örnekleme tekniği kullanılarak 30 dördüncü sınıf öğrencisi ile yürütülmüştür. Çalışmada karma araştırma deseni temel alınmıştır. Veri toplama aracı olarak başarı testi, ögretim materyalleri motivasyon anketi, AG tutum ölçeği ve yarı yapılandırılmış görüşme formu kullanılmıştır. Verilerin analizi için ilişkili ve ilişkisiz örneklemler için $t$ testi, frekans yüzde ve ortalama değerlerine yönelik betimsel istatistikler ve içerik analizi ile veriler değerlendirilmiştir. Araştırma sonucunda disiplinler arası kavram modeli odak seçilerek arttırılmış gerçeklik teknolojisinin ögretime entegre edilmesi ile gerçekleştirilen ögretimin deney grubu ögrencilerinin sosyal bilgiler ve matematik derslerinde başarlarını anlamlı şekilde arttırdı̆̆ı̆ı sonucu elde edilmiştir. Ayrıca öğrencilerin arttırılmış gerçeklik teknolojisi ile hazırlanmış materyallere yönelik olarak motivasyonlarının ve AG uygulamalarının kullanılmasına yönelik tutumlarının yüksek düzeyde olduğu belirlenmiştir. Öğrencilerin gerçekleştirilen ögrretim uygulamalarına ilişkin görüşlerine ait içerik analizi sonuçlarında ise görüşlerin duygu ve düşünceler, olumlu yönler, olumsuz yönler, AG uygulamalarının ögretimde kullanımı başlıkları altında dört tema altında gruplandı̆̆ belirlenmiştir.

Anahtar kelimeler: Artırılmış gerçeklik, disiplinler arası kavram modeli, materyal motivasyon, tutum.

*Filiz DİKKARTIN ÖVEZ, f.tubadikkartin@gmail.com, http://orcid.org/ 0000-0003-2646-5327 Burcu SEZGINSOY ŞEKER, sezginsoy @balikesir.edu.tr, http://orcid.org/ 0000-0001-9861-5174 


\title{
An interdisciplinary teaching application with augmented reality support in primary education
}

\begin{abstract}
The study aims to design activities for the application of augmented reality supported materials developed based on an interdisciplinary perspective and to examine the effect of education on the success, material motivations, attitudes, and opinions of the students. For this purpose, the application of augmented reality supported materials and activities were organized by integrating the learning outcomes determined within the scope of primary school social studies and mathematics curriculum. The research was conducted with 30 fourth-grade students using the criterion sampling technique which was one of the purposeful sampling methods. Data collection tool as an achievement test, Instructional Materials Motivation Survey, AG attitude scale was used and a semi-structured interview form. For the analysis of the data, $t$-test for related and unrelated samples, descriptive statistics for frequency percentage and mean values, and content analysis were used to evaluate the data. As a result of the research, it was concluded that the teaching carried out by integrating augmented reality technology into teaching by choosing the focus of the interdisciplinary concept model significantly increased the success of the experimental group students in social studies and mathematics courses. In addition, it was determined that the students motivation towards the materials prepared with augmented reality technology and their attitudes towards the use of (AR) applications were at a high level. In the content analysis results of the students; views on the teaching practices, it was determined that the views were grouped under four themes under the headings of feelings and thoughts, positive aspects, negative aspects, and the use of AR applications in teaching.
\end{abstract}

Keywords: Augmented reality, interdisciplinary concept model, material motivation, attitude, achievement.

\section{Giriş}

Teknoloji alanındaki hızlı gelişmelerin etkisiyle toplumlar arasında meydana gelen ayrım; her türlü teknolojik imkânın bulunduğu bir çevrede doğan ve bu teknolojik olanakları en etkili şekillerde kullanabilen öğrencilerin öğrenme ortamlarına dair talepleri de etkilemiştir. Önceleri teknolojiyi öğrencilerin belli kavramları tam olarak öğrendikten sonra kullanmasına izin veren, bir konunun özel yöntemlerle öğrenileceğine ve teknolojinin öğrenmeye engel olacağına dair var olan anlayış yerini bilgi ve iletişim teknolojilerinin (BİT) eğitime entegrasyonuna bırakmıştır [1].

Bu anlayış uygulanan öğretim programlarında ve standartlarda da değişime yol açmıştır. Uluslararası Eğitim Teknolojileri Birliği-ISTE (ISTE-International Society for Technology in Education) [2] tarafindan 2017 yılında geliştirilen standartlarda öğretmenlerden teknoloji okuryazarı olması, derslerinde teknolojiyi kullanabilmesi, öğrencileri teknolojiyi kullanmaya sevk etmesi, öğrenme çevresini öğrencilerin teknolojiyi kullanabilecekleri biçimde düzenleyebilmesi ve meslektaşları ile internet üzerinden iş birliği yapabilmesi beklenmektedir. Türkiye'de MEB tarafindan yayınlanan "öğretmenlik mesleği genel yeterliklerinde" de öğretmenlerin teknolojiyi 
kullanabilen ve bu konuda öğrencilerine model olabilen kişiler olabilmesi, BİT kullanımını ders planına ve öğrenme ortamlarına yansıtabilmesi vurgulanmaktadır. Son yıllarda, birçok çalışma eğitim kalitesini artırmak için bilgi ve iletişim teknolojilerinin (BİT) olanaklarını ve potansiyel faydalarını vurgulamaktadır. UNESCO'e göre BİT "bilgi toplumlarını kurmak için önemli bir araç" olarak ifade edilmektedir [3].

Eğitimde teknoloji entegrasyonuna dair net bir tanımlama bulunmamasına rağmen bazı araştırmacılar teknoloji entegrasyonunu sinıflarda öğretmenlerin bilgi-iletişim teknolojilerini kullanmaları olarak tanımlamaktadır [4,5]. NCES'ye göre teknoloji entegrasyonu BİT'in günlük yaşam ve öğretim programları ile bütünleştirilmesi olarak tanımlanmaktadır [6]. Niess, öğrencilerin düşünme becerilerini geliştirmek için öğretmenlerin teknoloji kullanmasını teknoloji entegrasyonu olarak tanımlamaktadır [1].

Teknoloji entegrasyonu üzerine yapılmış pek çok tanım ve model söz konusudur. Etkili teknoloji entegrasyonunun gerçekleştirilmesinde okul kültürü, teknolojik alt yap1, öğretmen bilgisi, öğrenci tutumları ve becerileri, pedagojik tercihler, öğretim stratejileri, planlama ve tasarım gibi farklı boyutlarda pek çok değişken etkendir. Değişkenlerin çokluğu ve etkileri nedeni ile teknolojiyi öğretime entegre sürecinde pek çok engel yer almaktadır. $\mathrm{Bu}$ engeller arasında öğretmenlerin teknoloji kullanım bilgisindeki eksiklikler, pedagojik ve alan bilgisindeki eksiklikler, çeşitli teknolojilerin öğretimde nasıl kullanılabileceği ve seçilebileceği bilgisi ile herhangi bir içerik alanında öğretim ile teknolojiyi bütünleştirme bilgi ve becerilerinde yer alan eksiklikler sıralanabilir [7].

Hew ve Brush teknolojiyi öğretim amaçlı olarak müfredata entegre ederken tipik olarak karşılaşılan engelleri tanımladığ çalışmasında 123 engel tespit etmiştir. Bahsedilen engeller şunlardır: a) kaynaklar, (b) bilgi ve beceriler (c) kurum, (d) konu kültürü, (e) tutum ve inançlar, (f) değerlendirme[4]. Kaynaklar teknoloji entegrasyonunda yaşanan teknoloji, teknolojiye erişim, zaman ve teknik destek sorunları olarak açıklanmakta ve yeterli donanım yazılım ve erişim olmadan öğretmenlerin öğretim sürecine teknolojiyi entegre etmesinin imkansız olduğu vurgulanmaktadır. Bilgi ve beceriler; teknoloji destekli pedagojik bilgi ve beceriler, teknoloji ile ilgili sınıf yönetimi bilgi ve becerileri; teknolojinin öğretim ile bütünleşmesinin önündeki en büyük engel olarak tanımlanmaktadır. Kurumsal engeller ise okul yönetiminden kaynaklanan engeller, öğretim programının uygulanması konusundaki zaman problemi ve okul planlamasındaki eksiklilerdir. Öğretmenlerin teknolojiye yönelik tutumları ve öğretmeöğrenme ile ilgili pedagojik inançları kişinin tutumunu belirleyeceğinden teknoloji ile ilgili negatif inançların teknoloji entegrasyonunun sağlanmasında önemli bir engel olarak görülmektedir. Teknolojinin entegre edildiği öğretim sürecinde değerlendirme önemli bir unsur olmasına rağmen öğretmenlerin teknolojik yazılımları ve araçları kullanmadan değerlendirme yapmayı tercih etmeleri diğer bir engeldir. Belli bir okul konusunun etrafında büyüyen kurumsallaşmış uygulamalar ve beklentilerin genel seti olarak tanımlanan konu kültürü öğretmenlerin bir konunun normlarıyla uyumsuz gördükleri bir teknolojiyi kesinlikle benimsememesiyle ilgili bir engeldir [8]. Resim dersinde teknolojiyi entegre etme konusundaki direnç örnek olarak gösterilebilir. Teknoloji entegrasyonu sürecinde bahsedilen bariyerler birbiri ile ilişkili görülmektedir. Örneğin tutum ve inançtaki değişimi kolaylaştırmak için öğretmenlerin bilgi ve becerileri, konu kültürü, değerlendirme ve kurum desteği olmak üzere dört faktörün dikkate alınması gerektiğini önerilmektedir [4]. Görüldüğü gibi eğitimde BİT entegrasyonu çok değişkenli bir denklemdir. $\mathrm{Bu}$ nedenle öğretmenlerin BİT 
entegrasyonu uygulamalarına başlamadan önce planlamanın nasıl olması gerektiği önemlidir. Örneğin, öğretmenler belirli bir disiplin alanda yer alan konu ve kavramlar için uygun BİT araçlarını seçmek, mevcut kaynakları değerlendirmek ve değiştirmek, öğrenci gruplarının özellikleri doğrultusunda öğretim etkinlikleri geliştirmek ve teknolojinin öğrencilerin bilgisini oluşturmalarına katkı sağlayacak biçimde kullanılmasını sağlamak ve öğrenci bilgisini değerlendirmek zorundadırlar [9].

Yirmi birinci yüzyıl dünyası sınırsız bilgi paylaşımı sağlayan iletişim ağları ile birbirine bağlı ve bağımlı hale gelmiştir. Yeni iş birliği biçimlerini ve yeni alanların ortaya çıkmasına neden olan bu değişim farklı disiplinlerin ve bilgilerin bütünleştirilmesini ve teknoloji ile entegre edilen ortamları gerekli kılmaktadır. Öğretim sürecinin parçası olan öğretmen ve öğrenciler bilimsel, çevresel, sosyal, ekonomik, kültürel ve teknolojik konularla ilişkili pek çok farklı bilgi türü ile karşılaşmaktadırlar. Bu konularla başa çıkmak için yeni teknolojiler ve iletişim araçlarının gelişmesi ile daha karmaşık hale gelmiş olan sosyal hayatta sorunlara farklı bakış açıları ile cevap bulabilen, disipliner ve disiplinler arası teknikleri teknolojiyi entegre ederek kullanan hayat boyu öğrenme alışkanlığ kazanmış bireyler başarılı olmaktadır. Bu yüzden üretim odaklı bireylerin yetiştirilmesine olanak sağlamak için öğretim programlarının STEM - eğitimine yöneldiği günümüzde disiplinler arası öğrenme çevrelerinin oluşturulmasına ihtiyaç vardir.

$\mathrm{Bu}$ çalışmada; teknoloji entegrasyonu sayesinde öğrencinin bilgiyi çeşitli teknolojileri bir -öğrenme aracı olarak kullanarak öğrenmeleri için firsat sağlanmaktadır. Bu süreçte üst düzey düşünme aktiviteleri tasarlayarak öğrenme temel alınmıştır. Geleneksel olarak verilen eğitim ortamlarında kullanılan ders kitabı, tarih şeritleri, tahta kullanımı, eğitim videoları gibi klasik eğitim materyalleri öğretmenlerin öğrencilerle olan etkileşiminde yetersiz kalmakta yeni neslin taleplerini karşılayamamaktadır. Bu doğrultuda yeni teknolojiler bu talepleri karşılamak amacıyla klasik öğretim materyali anlayışını değiştirerek faklı uygulamaların öğretim ortamına katılmasına neden olmaktadır. Öğrencilere dijital öğrenme deneyimleri sağlamayı amaçlayan etkileşimli simülasyonlar, eğitim oyunları, görsel gerçeklik, Artırılmış Gerçeklik (AG) gibi uygulamalar öğrenme ortamlarının bir parçası haline gelmeye başlamıştır. Bu kapsamda dijital öğrenme deneyimleri öncelikle masaüstü bilgisayarlar ve interaktif beyaz tahtalarla donatılmış sınıflarda erişilebilir hale gelmiş, daha sonra akıllı telefonlar ve tabletler gibi taşınabilir aygıtlar aracılığıyla her ortamda öğrencilerin öğrenme deneyimlerine ulaşmalarına imkân sağlamıştır [10].

$\mathrm{Bu}$ noktada öğrenme ortamlarında sunulan araç gereçlerin zenginleştirilmesi amaciyla pek çok farklı teknolojiler "yazılımlar, etkileşimli uygulamalar, sosyal ağlar, web 2.0 ve web 3.0 araçları." kullanılmaya başlanmıştır. Bu uygulamalardan birisi de mobil AG uygulamalarıdır [11].

Sanal ortamlardaki nesneleri gerçek nesnelere entegre eden uygulamalardan birisi arttırılmış gerçekliktir. Ders kitaplarını akıllı kitaba, bir öğrenme nesnesi olarak kullanılan fotoğrafi; video ya da üç boyutlu bir görsele dönüştürebilen bu teknolojiler öğrenenlerin motivasyonlarını ve başarılarını arttırmada etkili bir materyal olarak kullanılmaya başlanmıştır. AG sanal dünyada yer alan bilgilerle bir dijital dünya oluşturarak duyuları (görme, işitsel ve dokunsal) en üst düzeyde dijital araçlarla kullanma imkânı veren bir uygulamadır. Artırılmış gerçekliğin; gerçek ve sanalı 
birleştirmesi, eş zamanlı etkileşim ya da gerçek zamanlı etkileşim sağlaması ve üç boyutlu ortamda konumlandırılma olmak üzere üç temel özelliğe sahiptir [12].

AG sistemleri işaretleyici tabanlı ve işaretleyici tabanlı olmayan uygulamalar olmak üzere iki gruba ayrılabilir [13]. İşaretletiyici tabanlı uygulamalar, işaretleyici bilgi sunmak için bir kitapçık, kitapçıtan bilgi almak ve onu başka bir veri türüne dönüştürmek için bir yer tutucu ve bir ekranda bilgileri 3D işlenmiş bilgiye arttırmak için bir küp içeren üç temel bileşenden oluşur. İşaretleyici tabanlı olmayan uygulamalar, GPS'i içeren bir izleme sistemine ihtiyaç duymaktadır. Bu uygulamalar, özel etiketleme veya ek referans noktalarına ihtiyaç duyulmadan her yerde işlev gördükleri için daha geniş uygulanabilirliğe sahiptir. AG, son yirmi yılda klasik eğitim ve öğretim yöntemleri kadar olmasa da hem okul hem de iş ortamlarında deneysel olarak uygulanmıștır. Bunun yanında AG bilgisayar ve mobil cihazlardan herkes tarafından ulaşılabilir olduğu için cazip bir öğretim uygulaması olarak görülmektedir [14].

AG, öğrencilerin daha fazla duyu organına hitap ederek öğrenme öğretme sürecinde öğrenci anlayışının artmasına yardımcı olan bir teknolojidir. AG etkinlikleri öğrenme ve öğretim sürecinde, öğrencilerin soyut kavramları anlamalarına yardımcı olduğu gibi bilgi paylaşımı yapabilme imkânı sağlamaktadır. Ayrıca kullanıcıların sanal nesnelerle, gerçek ortamda eş zamanlı etkileşim kurarak, gerçek dünya ortamı ve sanal nesnelerle doğal etkileşim kurabilmesini sağlar [15]. Literatürde bu teknolojinin kullanımının eğitim ortamı a etkilerine ilişkin pek çok çalışma bulunmaktadır. Artırılmış gerçekliğin eğitim ortamlarına katkılarına ilişkin yapılan çalışmalar Tablo 1'de yer almaktadır.

Tablo 1. Artırılmış Gerçekliğin Eğitim Ortamlarına Katkıları

\begin{tabular}{|l|l|}
\hline AR uygulamalarının katkıları & Araştırmacı(lar) \\
\hline Derse karşı olumlu tutum geliştirir. & {$[16-19]$} \\
\hline İlgiyi arttırır. & {$[20,21]$} \\
\hline Dikkati çeker. & {$[22-24]$} \\
\hline Motivasyonu arttırır. & {$[17,21,22,25,26,27]$} \\
\hline Başarıyı arttırır. & {$[15,18,28,29,30]$.} \\
\hline Somutlaştırmayı sağlar. & {$[15,16,31-34]$} \\
\hline Kavram yanılgılarını azaltır. & {$[15,35]$} \\
\hline Öğrenmeyi eğlenceli hale getirir. & {$[15,36-39]$} \\
\hline Kalıcı öğrenmeyi sağlar. & {$[19,40]$} \\
\hline Derse katılımı arttırır. & {$[15,22,41]$} \\
\hline $\begin{array}{l}\text { Karmaşıı kavramların, konuların veya teorilerin } \\
\text { anlaşımasına yardımcı olur. }\end{array}$ & {$[42,43]$} \\
\hline $\begin{array}{l}\text { 21. yüzyıl öğrenme becerilerini (Eleştirel düşünme } \\
\text { becerileri, problem çözme becerileri ve iş birlikli } \\
\text { öğrenmeye dayalı...vb.) kullanmayı sağlar. }\end{array}$ & {$[44,45]$} \\
\hline
\end{tabular}

Tablo 1'de yer verilen sonuçların yanı sıra geometri, sosyal bilgiler ve diğer disiplin alanlarında yer alan soyut kavramların, sınıf ortamına getirilemeyecek materyallerin sanal ortamda görselleştirilerek anlamlı öğrenmeyi sağlamada etkili olduğu [46-48] gerçek dünyada yaşanması mümkün olmayan bilimsel olguları (örneğin kimyasal reaksiyonlar, fotosentez süreci, güneş sisteminin gözlemlenmesi) yaşama imkânı tanıyarak başarıyı arttırdığı $[42,43,77]$ sonuçlarına yapılan çalışmalarda ulaşılmıştır. 
Literatürde yer alan çalışmaların olumlu sonuçlarının yanında eğitim ve öğretim ortamında AG destekli uygulamaların gerçekleştirilmesi dijital göçmenler olarak görülen bir kısım öğretmenin yeni teknolojilere karşı olan direnci ve maliyet sorunları nedeniyle halen zorlayıcı görülmektedir [14].

Var olan bu dirence rağmen öğrencilerin yeni teknolojilere (görsel gerçeklik, AG, dokunmatik ekranlar, akıllı uygulamalar ve mobil cihazlar) karşı ilgisi giderek artmaktadır. Yapılan çalışmalar incelendiğinde AR uygulamalarının öğrencilerin öğrenme ortamına girme arzusu olarak tanımlanan motivasyonu arttırdığı görülmektedir $[26,27]$.

Ibanez ve ark. (2011) artırılmış gerçekliğin etkisini araştırdıkları çalışmalarında İspanyolca öğretiminde artırılmış gerçeklerin kullanılmasının öğrencilerin motivasyonlarını ve öğrenme çıktılarını artırdığını ortaya koymaktadır [49]. Dunleavy, Dede ve Mitchell (2009), okullarda öğrencilerin, AG simülasyonlarının matematiği ve okuryazarlık becerilerini geliştirmelerine nasıl yardımcı olduklarını araştırmışlardır [41]. Çalışma sonuçlarına göre AG teknolojisinin öğrencilerin öğrenmesini arttırmada etkili olduğu, öğrencilere eleştirel düşünme becerileri, problem çözme becerileri ve iş birliğine dayalı öğrenme becerilerini kullanmada ortam yarattığı ve firsatlar sunduğunu ortaya koymuşlardır. Ayrıca çalışma sonucunda gelecekte GPS özellikli cep telefonlarıyla arttırılmış gerçekliğin birleşmesi sonucu derse karşı en ilgisiz öğrenciyi bile motive etmek için bu teknolojinin benzersiz bir kaynak olacağ belirtilmiştir.

Fen bilgisi öğretiminde AG kullanımının öğrencilerin geleneksel öğretim metodolojisinden çok daha fazla kavramsal öğrenmeyi sağladığı ayrıca, öğrencilerin motivasyonunu, ilgisini ve performanslarını artırmak için yararlı bir araç olduğunu ortaya konulmuştur $[21,76]$. Yabancı dil öğretiminde ise AG ile motivasyon modelini birleştirdiği çalışmalarının sonucunda öğrencilerin modelde yer alan motivasyon faktörlerinden dikkat, uygunluk, güven ve doyum düzeyleri ile genel motivasyon düzeylerinin arttığg sonucuna ulaşılmıştır [50]. Di Serio, Ibáñez, ve Kloos 'un tarafından ortaokul öğrencilerine yönelik olarak görsel sanatlar dersi kapsamında yapılan çalışmada slayt destekli olarak kullandıkları materyaller ile AR destekli ses, video ve üç boyutlu nesne özellikleri içeren iki farklı materyalin motivasyona etkisi karşılaştırılmış, motivasyonun AG destekli materyaller lehine anlamlı șekilde daha yüksek olduğu belirlenmiştir [27]. Radu, yaptığı çalışmalarda AG uygulamaları ve AG kullanılmayan öğrenme ortamlarına ilişkin yaptığı karşılaştırmalı çalışmalarda AG uygulamalarının başarıyı, iş birliği ve motivasyonu artırmada olumlu olarak etkili olduğunu belirlemiştir [10]. Bacca, Baldiris, Fabregat, Graf, Kinshuk (2014), tarafından yapılan meta analiz çalışmasında $A G$ ' nin eğitimdeki uygulamaları üzerine yapılan 32 çalışma incelenmiştir [51]. Elde edilen bulgular ışığında AG destekli eğitim uygulamalarının en çok öğrenme çıktılarını $(\% 43,7)$, motivasyonu $(\% 31,2)$, artırmada etki olduğu; bunun yanında olumlu tutumu, ilgiyi, öğrenci katılımını, farkındalığı artırmada ve öğrenci beklentilerini karşılamada etkili olduğu belirlenmiştir.

Bilindiği gibi öğrenci motivasyonu derse katılımı, ilgiyi, başarıyı artırmada etkili bir unsurdur [52]. Yapılan çalışmalar motivasyonun öğrencilerin öğrenmelerine yardımcı olacak etkinliklere katılma olasılığını arttırdığını ve daha iyi performans elde edildiğini ortaya koymuştur. Böylece, öğrencilerin ilgisini çeken ve onlarla bütünleşen öğrenme stratejileri sayesinde öğrencilerin başarılarını ve konuya derinlemesine bağlanmalarını olumlu yönde etkilemektedir [53]. 
Keller (1983) etkili bir öğretim tasarımında motivasyonun önemli bir değişken olduğunu, öğrencilerin motive edildiğinde daha yüksek başarı gösterdiklerini ileri sürmektedir [54]. Keller $(1983,1987)$ in ortaya koyduğu ve birçok motivasyon modeli analiz edilerek geliştirilen ARCS Motivasyon Modeli kapsamında belirlenen dört temel strateji bileşenleri Dikkat (Attention), Uygunluk (Relevance), Güven (Confidence) ve Doyum (Satisfaction) olarak tanımlanmaktadır [54-55]. Keller'in modelinde öğrencilerin dikkatini kazanması ve sürdürmesine ve buna bağlı olarak öğrenme meraklarını teşvik etmesinde motivasyonel bir tasarım süreci önemli görülmektedir. Öğrenme motivasyonu ile ilişkili problemlerin teşhisi için tanımlayıcı bir model olarak geliştirilen ARCS motivasyon modelini temel alarak öğrenen motivasyonunu ölçmek için Keller (2010) tarafından geliştirilen ölçek motivasyonu ölçmek amacıyla kullanılmaktadır [56].

Teknolojinin kullanıldığ 1 öğrenme ortamlarının, öğrenci motivasyonunu ve başarısını artırmada etkili olduğunu gösteren literatürde pek çok çalışma yer almaktadır. Ancak içerisinde soyut kavramlar barındıran ve kendine ait dil ve terminolojiye sahip olan matematik dersinin anlaşılması ve anlamlandırılabilmesi için bu kavramların öğretiminde günlük hayatla ilişkilendirmek önemlidir. Anlamlı öğrenmeyi sağlamak için, öğrencilerin matematiğin sosyal hayatta kullanımını fark etmeleri ve uygulayabilmeleri gerekir.

$\mathrm{Bu}$ kapsamda çalışmanın amacı disiplinler arası AG destekli öğretimin öğrencilerin sosyal bilgiler ve matematik başarılarına etkisini, kullanılan AG materyallerine yönelik motivasyonlarını, AG'ye yönelik tutumlarını ve AG destekli öğretim uygulamalarına yönelik görüşlerini incelemektir. Bu amaç doğrultusunda ilkokul 4. sınıf sosyal bilgiler ve matematik dersi öğretim programları kapsamında belirlenen kazanımlar, disiplinler arası kavram modeli temel alınarak bütünleştirilmiş ve bir öğretim planı geliştirilmiştir. Araştırma soruları şöyledir.

1. AG destekli disiplinler arası öğretim uygulamaları sonucunda deney grubu öğrencilerin sosyal bilgiler ve matematik dersi ön test-son test başarı puanları arasında anlamlı farklılık var midir?

2. Öğrencilerinin disiplinler arası (AG) uygulamalarının kullanılmasına yönelik tutumları nasıldir?

3. AG destekli disiplinler arası öğretimde kullanılan öğretim materyallerine yönelik öğrencilerin materyal motivasyon düzeyleri nasıldır?

4. Öğrencilerin disiplinler arası AG uygulamalarına yönelik görüşleri nasıldır?

\section{Yöntem}

\subsection{Araștırmanın modeli}

$\mathrm{Bu}$ araştırmada karma yöntem araştırmalarından iç içe desen çalışmanın modeli olarak seçilmiştir. İç İçe desen, nicel ve nitel desenlerin bir araya getirildiği yaklaşım olarak belirtilmiştir. Bir veya daha fazla veri türünün (nicel veya nitel) yer aldığı desendir. Araştırma verileri, nicel ve nitel desenler içinde toplanır ve çözümlenir [57]. Araştırmanın nicel kısmından ön test-son test tek gruplu deneysel desen kullanılmıştır. Deneysel desen, değişkenler arasındaki neden-sonuç ilişkisini test etmeye yönelik araştırmalardır. Tek gruplu ön test-son test modelinde bir gruba bağımsız değişen uygulanır ve uygulama öncesi ve sonrası ölçme yapılır. Modelde grubun ölçme 
araçlarından aldıkları ön ve son test puanlarının aritmetik ortalaması arasında anlamlı farklılık varsa uygulamanın etkili olduğu kabul edilir [58,59]. Yeni bir eğitim modülünün geliştirilip uygulandığı araştırmalarda tek gruplu deneysel desenin tercih edilmesi araştırmanın doğası gereği kabul edilmektedir [60].

Araştırmanın nitel kısmında ise durum çalışmasından yararlanılmıştır. Nitel araştırma yöntemlerinden durum çalışması, belirli bir zaman diliminde gerçekleşen durumların, kendi içinde bütün hâlinde olduğu kesin sınırlarının çizilmesinin zor olduğu, çoklu kaynakları içeren görüşmeler, gözlemler, doküman gibi veri toplama araçları ile derinlemesine incelenen durumların tanımlandığı araştırma yöntemi olarak tanımlanmaktadır [61]. Bu çalışmada disiplinler arası kavram modeli temel alınarak AG materyalleriyle zenginleştirilmiş öğretim uygulamalarına yönelik öğrenci görüşleri yarı yapılandırılmış görüşmeler ile belirlendiğinden araştırmanın nitel boyutunda durum çalışması temel alınmıştır. Ayrıca disiplinler arası uygulamanın öğrencilerin AG tutum, Materyal motivasyon düzeyleri son test ile matematik ve sosyal bilgiler başarılarına etkisi ise ön-son test uygulamaları ile belirlenmiştir.

\section{2 Çalışma grubu}

Araştırmanın çalışma grubunu Balıkesir il merkezinde bulunun bir özel okulda öğrenim görmekte olan 30 dördüncü sınıf öğrencisi oluşturmaktadır. Öğretim süreci için gerekli olan tablet ve akıllı tahta gibi alt yapı donanımına sahip bir özel okul tercih edilmiştir. Amaçlı örnekleme yöntemlerinden ölçüt örnekleme tekniği kullanılarak ilgili okulda öğrenim gören ve üç yıldır derslerinde tablet ve akıllı tahta kullanmış olan 30 öğrenci (12 kız,18 erkek) çalışmanın örneklemini oluşturmaktadır.

\subsection{Veri toplama araçları}

Çalışmada belirlenen kazanımların bütünleştirilmesi ile içeriğe yönelik olarak geliştirilen AG öğretim materyalleri hakkındaki öğrenci motivasyonlarını ölçmek için "Materyal Motivasyon Anketi" kullanılmıştır. Çalışma esnasında etik kurul onayı için Balıkesir Üniversitesi'ne başvurulmuş ve araştırma etiğine aykırı bir durum olmadığ 1 25.02.2021 tarihli ve 52899066/302.08.01/13384 sayıl1 etik kurul izin belgesi ile onaylanmıştır. Keller tarafından ARCS Motivasyon Modeline dayalı öğretim materyallerinin motivasyonları üzerindeki etkisini ölçmek için geliştirilen anket, Kutu ve Sözbilir tarafından Türkçeye uyarlanmış, geçerlik ve güvenirlik çalışması yapılmıştır [62]. Yapılan geçerlik ve güvenirlik çalışması sonucunda elde edilen anket "dikkat-uygunluk" ile "güven-tatmin" olmak üzere iki faktörlüdür ve 24 maddeden oluşmaktadır. Ölçeğin Cronbach Alpha iç tutarlılık katsayısı tüm anket için 0.83, alt faktörler için sırasıyla 0.79 ve 0,69 olarak bulunmuştur.

Gerçekleştirilen uygulamanın öğrenci başarısına etkisini incelemek amacıyla veri toplama aracı olarak araştırmacılar tarafından açık uçlu sorulardan oluşan başarı ölçeği geliştirilmiştir. Ölçek geliştirme sürecinde 4. sınıf matematik ve sosyal bilgiler öğretim programı kapsamında araştırmacılar tarafından belirlenen birbiri ile ilişkilendirilmiş konular ele alınmıştır. Programda yer alan kazanımlar arasında yeterli ve ayrıntılı bir ilişkilendirme yer almadığı için program değerlendirme uzmanlarının görüşleri doğrultusunda kazanımlar belirlenen kavram çerçevesinde birbirine entegre edilmiştir. Buna göre sosyal bilgiler dersi kronolojik sıralama ve sözlü tarih yöntemi kullanılarak aile tarihinin yapılandırılması konuları ile matematik dersi yıl-ay-hafta, ay-hafta-gün arasındaki dönüştürmeler ile zaman ölçü birimlerinin kullanıldığı günlük hayat problemleri konuları ilişkilendirilmiştir. Bu kapsamda matematik ve sosyal bilgiler 
kapsamında belirlenen konular çerçevesinde madde havuzu oluşturulmuştur. Maddelere ilişkin sosyal bilgiler ve matematik alan eğitimi uzmanları ile iki temel eğitim alan uzmanı ve iki sınıf öğretmeninden oluşan altı kişilik uzman grubunun; soruların öğrencilerin seviyesine, öğretim programına uygunluğu konusunda görüşleri alınmıştır. Elde edilen görüşler çerçevesinde oluşturulan madde havuzunda yer alan 20 soru ölçekten çıkartılmış 17 (8 sosyal bilgiler, 9 matematik) maddelik ölçek oluşturulmuştur. Soruların anlaşılırlığı, uygulanma süresi gibi konuların değerlendirilmesi için asıl uygulama öncesi Çalışma grubunda yer almayan pilot çalışma grubunda olan 20 öğrenciye ölçek uygulanmış anlaşılırlığında bir sorun olmadığı tespit edilen ölçeğe son hali verilmiştir.

Gerçekleştirilen öğretim uygulamalarının öğrencilerin AG uygulamaları tutumlarına etkisini incelemek amacı ile Küçük, Yılmaz, Baydaş ve Göktaş tarafından geliştirilen üç faktörlü 15 maddeden oluşan "AG Uygulamaları Tutum Ölçeği” kullanılmıştır [63]. Ölçeğin iç tutarlılık güvenirlik katsayısı ölçeğin tamamı için .83 olarak bulunmuştur. Birinci faktör "kullanma memnuniyeti", ikinci faktör "kullanma kaygısı", üçüncü faktörde "kullanma isteği”" olarak isimlendirilmiştir. Elde edilen faktörlere ve ölçeğin tümüne yönelik uygulanan iç tutarlılık (Cronbach alpha) analizi de ölçeğin güvenilir olduğunu göstermiştir (Ölçeğin tümü $\alpha=.835 ; 1$. faktör $\alpha=.862$; 2.faktör $\alpha=.828$; 3. faktör $\alpha=.644)$. AFA ile elde edilen yapıya katkı sağlamak amacıyla DFA gerçekleştirilmiştir. Ölçeğin iç tutarlılık güvenirlik katsayısı ölçeğin tamamı için .83 olarak bulunmuştur. Elde edilen sonuçlar ortaya çıkan yapının kabul edilebilir olduğunu göstermiştir. Ölçekte belirlenen birinci faktörde öğrencilerin AG uygulamalarına yönelik memnuniyet düzeylerini ortaya çıkaracak 7 olumlu ifade; ikinci faktörde öğrencilerin AG uygulamalarının kullanılmasına yönelik kaygılarını ortaya çıkaracak 6 olumsuz ifade, üçüncü faktörde ise öğrencilerin $A G$ uygulamalarını gelecekte kullanma isteklerini ortaya çıkaracak 2 olumlu ifade yer almaktadır.

Uygulamaya katılan öğrencilerin görüşleri yarı yapılandırılmış görüşme tekniği ile toplanmıştır. Bu amaçla araştırmacılar tarafından literatür taraması yapılarak görüşme formu geliştirilmiştir. Görüşme sorularının iç geçerliğini sağlamak için uzman görüşü alınmıştır. Ayrıca görüşme formu için sınıf öğretmenin de görüşlerine başvurulmuştur. Soruların anlaşılırlığı, ortalama görüşme süresinin tespiti için pilot uygulamaya katılan iki öğrenci ile ön deneme görüşmesi gerçekleştirilmiştir. Öğrencilerin anlamakta ya da cevaplamakta zorlandıkları maddeler ve ek sorular uzman görüşü doğrultusunda yeniden düzenlemiş, alternatif sorularla desteklenmiştir. Görüşmeler yüz yüze gerçekleştirilmiştir. Ortalama her öğrenci için 15-20 dakika süren 30 öğrenciden elde edilen görüşme verileri ses kayıt cihazı ile kaydedilmiş ardından yazıya dökülerek analize hazır hale getirilmiştir. 8 maddeden oluşan görüşme formu kapsamında öğrencilere AG destekli materyalleri derste kullanmanın sonucundaki deneyimleri, bu deneyimden hoşlanıp hoşlanmadıkları, bu tip materyallerin öğretim sürecinde kullanılmasına yönelik düşünceleri, yapılan uygulamalarda en çok hoşlandıkları noktaların neler olduğu, bu tip çalışmaların diğer derslerde kullanılmasına yönelik düşünceleri ve uygulamalar sırasında en çok zorlandıkları noktaların neler olduğuna ilişkin çeşitli sorular yöneltilmiştir.

\subsection{Verilerin analizi}

Araştırmanın amacı doğrultusunda gerçekleştirilen uygulamanın öğrencilerin matematik ve sosyal bilgiler başarılarına etkisi, geliştirilen öğretim materyallerine yönelik öğrencilerin motivasyonları, AG tutumları ve öğretim uygulamalarına yönelik görüşleri 
incelenmiştir. $\mathrm{Bu}$ süreçte uygulama öncesinde ve sonrasında deney grubundan elde edilen ön-son test başarı düzeyleri arasındaki farkın anlamlılığı ilişkili örneklemeler için $\mathrm{t}$ testi ile incelenmiştir. T-testinin uygulanabilirliği alınan puanların normal dağılımına ilişkin inceleme için Shapiro-Wilk normallik testi yapılmıştır. Çalışma grubu 50'den küçük olduğu için Shapiro-Wilk testi uygulanmıştır. Shapiro-Wilk testinin "Sig. $(p=.71) "$ değerleri $0.05^{\prime}$ ten büyük olup 0.05 anlamlılık seviyesinde deney grubu verilerinin normal dağılım gösterdiği söylenebilir.

AG öğretim materyallerine yönelik öğrenci motivasyonlarını belirlemek amacı ile uygulanan "Materyal Motivasyon Ölçeğin" den elde edilen veriler betimsel olarak değerlendirilmiştir. Veriler ayrıca ölçeğin faktörleri olan dikkat-uygunluk, güventatmin boyutları altında değerlendirilmiştir. Ölçekten elde edilen aritmetik ortalamalar yorumlanırken 1.00-1.80 arasındaki değerler "çok düşük", 1.81-2.60 arasındaki değerlerin "düşük", 2.61-3.40 arasındaki değerlerin "orta", 3.41-4.20 arasındaki değerler "yüksek" ve 4.21-5.00 arasındaki değerler "çok yüksek" derecesinde gerçekleştiği kabul edilmiştir [62]. Tutum verilerinin çözümlenmesi sürecinde, likert tipinde olan tutum ölçeğinin maddelerine yönelik analizler için frekans ve yüzde değerleri hesaplanmıştır. Ayrıca tutum ölçeğinde yer alan faktör puan ortalamaları hesaplanmıştır. Birinci faktör ölçekte "kullanma memnuniyeti", ikinci faktör "kullanma kaygısı", üçüncü faktörde "kullanma isteği”" olarak isimlendirilmiştir. Uygulamaya katılan öğrencilerin görüşlerine ilişkin verilerin analizinde içerik analizi kullanılmıştır. Elde edilen görüşler yazıya dökülmüş toplanan verilerin analizinde "kategorisel analiz" kullanılmıştır. Kategorisel analiz, genel olarak belirli bir mesajın önce birimlere bölünmesi ve ardından bu birimlerin önceden saptanmış ölçütlere göre kategoriler halinde gruplandırılmasıdır [64]. İçerik analizi sonucu kod ve temaların oluşturulmasında iki uzmanın görüşü alınmıştır. Kodlayıcılar arasındaki uyum \% 88 olarak hesaplanmıştır. Bu sonucun \%70'in üzerinde olması kod ve temaların güvenilir olduğunu göstermektedir [65]. Ayrıca oluşturulan temalar doğrudan alıntılarla desteklenmiştir.

\subsection{Süreç}

Çalışmanın amacı doğrultusunda ilkokul 4. sınıf sosyal bilgiler ve matematik dersi öğretim programları kapsamında belirlenen kazanımlar, disiplinler arası kavram modeli temel alınarak bütünleştirilmiştir. Bu modelin temel amacı farklı disiplinleri bir konu, problem veya tema etrafinda bir araya getirmektir [66]. Modelde disiplinlerarası bir öğretim ortamının nasıl geliştirileceğine yönelik dört aşamalı bir süreç tanımlanmaktadır. "Temel Kavramın Seçilmesi" olarak tanımlanan ilk aşamada disiplinlerarası yaklaşıma uygun olabilecek ve çeşitli disiplinleri bütünleştirebilecek özelliğe sahip kavram ya da konu seçimi söz konusudur. Bu amaçla "kronolojik sıralama" kavramı seçilmiştir. İkinci aşama "Beyin firtınası yardımcıları" aşamasıdır. $\mathrm{Bu}$ aşamada seçilen konu ya da kavrama ilişkin alt konu ve kavramlar beyin firtınası yöntemi ile belirlenerek ilişkili olabileceği disiplinler matematik ve sosyal bilgiler olarak seçilmiştir. Bu uygulamada seçilen kavramın en iyi öğretilebileceği disiplin alanlarının ortaya çıkarılması önemlidir. Bu nedenle her disiplin alanının sürece katılma zorunluluğu yoktur.

Bu kapsamda çalışmada, 4.sınıf sosyal bilgiler öğretim programında yer alan kronolojik sıralama ve sözlü tarih yöntemi konuları ile 4. sınıf matematik dersi öğretim programında yer alan yıl-ay-hafta, ay-hafta-gün arasındaki dönüştürme ve zaman ölçü birimlerinin kullanıldığ 1 günlük hayat problemlerini çözme ve kurma konuları, seçilen 
kavram ile ilişkilendirilmiştir. Üçüncü aşama olan "Rehber olacak soruların kapsam ve sırası" aşamasında belirlenen konular arasında sistematik bir yapı oluşturulacak şekilde soru ve problem durumları belirlenmiştir. Bu süreçte öğrencilere yöneltilecek soruların kavramlara yönelik olarak "ne?, neden?, niçin?, nasıl?" sorularını içerecek nitelikte düzenlenmiş olmasına (Jacobs, 1989; Lattuca, 2001; Rosenfield, 1992; Yıldırım, 1996) dikkat edilmiştir [67-70].

Dördüncü aşama olan "Plana dair etkinlik yazma" aşamasında geliştirilen sorulara uygun olarak ders planı etkinlikler ve arttırılmış gerçeklik materyalleri oluşturulmuştur. Bu aşamada üçüncü aşamada belirlenen sorulara bağlı olarak programın amaç, içerik, uygulama ve değerlendirme yöntemleri belirlenmiştir. Disiplinlerarası Kavram Modeli'nin özellikleri göz önüne alınarak seçilen kavramı ile matematik ve sosyal bilgiler disiplinlerini içine alan disiplinler arası kavramsal model Şekil 1 verilmiştir.

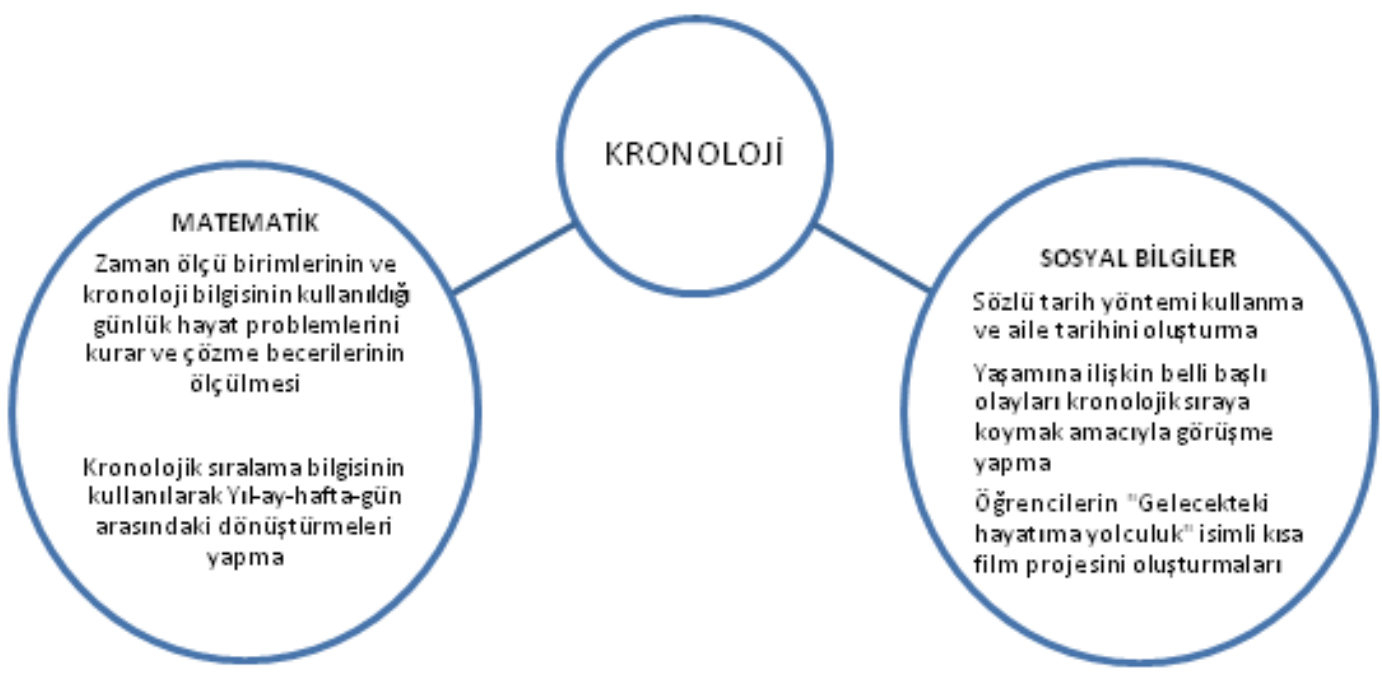

Şekil 1. Disiplinlerarası kavram modeli- "Kronoloji"

Yukarıda yer alan bu model doğrultusunda olarak ders planı etkinlikler ve arttırılmış gerçeklik materyalleri oluşturulmuştur. $\mathrm{Bu}$ amaçla ilk olarak geliştirilen üç AG materyalinde kullanılacak olan videolar; movie maker, photostory 3, camtasia 8 gibi web 2.0 araçları kullanılarak oluşturulmuştur. AG uygulaması geliştirme aşamasında Unity 3D oyun motoru programı Vuforia SDK kullanılmıştır. Geliştirilen uygulamalar hem Windows işletim sisteminde hem de android işletim sisteminde çalışabilecek biçimde tasarlanarak öğrencilerin kamera, tablet ve telefon kullanmalarına imkân sağlamak amaçlanmıştır. AG uygulamasının sanal videoların konumlandırılacağ1 yerlerin belirlenebilmesi için içeriklerle uyumlu hedef resimler obje olarak seçilmiştir. Hazırlanan AG materyallerinin hedef kitleye uygunluğu kullanışlılığı, tasarım ve teknik açıdan kriterlere uygunluğu (ses, görüntü, senaryo v.b.) için bilgisayar ve öğretim teknolojileri eğitimi alanında uzman iki öğretim üyesi, Matematik ve sosyal bilgiler eğitimi alanında uzman 2 öğretim üyesi ve 2 sinıf öğretmeninin oluşturduğu uzman grubunun görüşüne başvurulmuştur. Alınan görüşler doğrultusunda gerekli düzeltmeler yapılmış ve AG materyallerine son halleri verilmiştir. Geliştirilen öğretim planı ve AG materyalleri bir özel okulda 8 saat süresince 30 dördüncü sinıf öğrencilerine uygulanmıştır. Şekil 2 de Walt Disney'in biyografisi, doğum günü hikayesi, 
gelecekteki hayatıma yolculuk konulu arttırılmış gerçeklik materyallerine ait ekran görüntüleri Şekil 2 de verilmektedir.

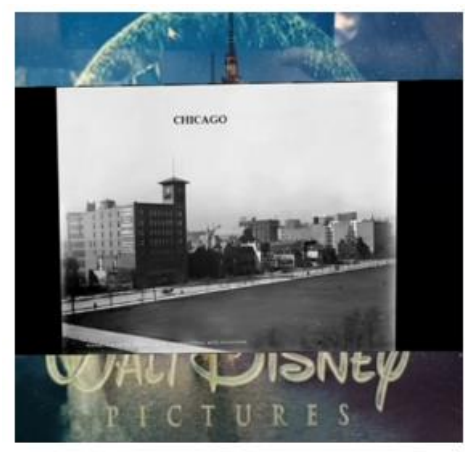

Walt Disney'in Hayatı

(Dijital hikaye)

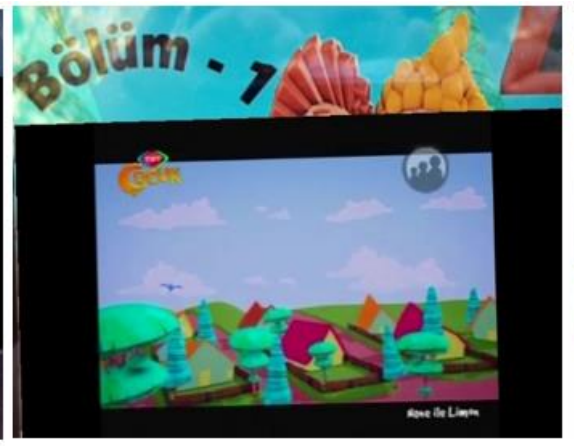

Nane Limon Animasyon

(Animasyon)

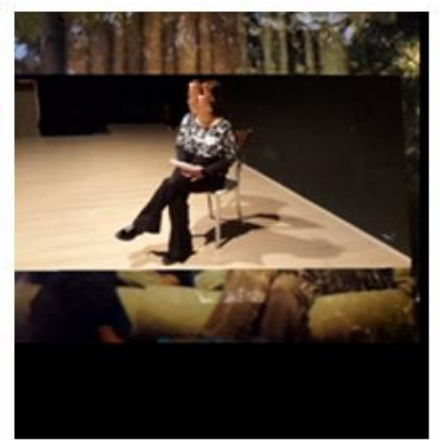

Gelecekteki hayatıma yolculuk

(Kendimle röportajım)

Şekil 2. AG materyalleri ekran görüntüleri

\section{Bulgular ve yorumlar}

Araştırmanında ilk olarak gerçekleştirilen öğretimin öğrenci başarısı üzerine etkisi incelenmiştir. $\mathrm{Bu}$ amaçla deney grubu sosyal bilgiler ve matematik dersi ön-son test başarı puanlarının ortalaması, standart sapması, ortalama farkı ve hesaplanan " $t$ " değeri tablo 2' de verilmiştir.

Tablo 2. Sosyal bilgiler ve matematik dersi ön-son test başarı puanlarının karşılaştırılması

\begin{tabular}{|c|c|c|c|c|c|c|c|}
\hline Grup & $\mathbf{N}$ & Test & $\mathbf{X}$ & Ss & Xfark & Sd & t \\
\hline \multirow{3}{*}{ Deney } & \multirow{3}{*}{ Matematik } & Son test & 4.90 & 0.84 & 3.90 & 28 & $14.01 *$ \\
\cline { 3 - 5 } & & On test & 1.0 & 1.3 & & & \\
\cline { 2 - 5 } & $\begin{array}{c}\text { Sosyal } \\
\text { Bilgiler }\end{array}$ & Son test & 4.93 & .94 & 3.57 & 28 & $11.12^{*}$ \\
\cline { 3 - 5 } & & On test & 1.36 & 1.54 & & & \\
\hline
\end{tabular}

Tablo 2 incelendiğinde deney grubu öğrencileri, uygulama öncesinde matematik ön testinden ortalama 1,00 puan, son testinden ise ortalama 4,90 puan elde etmişlerdir. Ayrica sosyal bilgiler ön testinden ortalama 1,36 puan, son testinden ise ortalama 4,93 puan elde etmişlerdir. Elde edilen sonuca göre deney grubu öğrencilerinin ön ve son başarı testlerinden aldıkları puanların ortalamaları arasında matematik son testi lehine 3,90 puanlık fark, sosyal bilgiler son testi lehine 3.90 puanlık fark bulunmaktadır. Bu farklar öğrencilerin matematik ve sosyal bilgiler erişi puanı olarak nitelendirilebilir. Öğrencilerin matematik ve sosyal bilgiler ön-son testinden elde ettikleri ortalama puanlar arasındaki farkın anlamlılığını belirlemek üzere yapılan paired $t$ testi sonuçlarına göre " $\mathrm{t}$ " değeri anlamlı bulunmuştur [ $\mathrm{t}_{\text {Matematik }}(2-28)=14.01 ; \mathrm{p}<.05, \mathrm{t}_{\text {sosyal }}$ bilgiler $(2-28)=11.12 ; \mathrm{p}<.05]$. 
Öğrencilerin AG materyallerine yönelik materyal motivasyon düzeyleri

Disiplinler arası kavram modeli temel alınarak AG teknolojisi ile hazırlanmış materyallere yönelik öğrencilerin motivasyonlarının değerlendirilmesi ve alt boyutlar olan dikkat-uygunluk, güven ve tatmin açısından sonuçları Tablo 3' de verilmektedir

Tablo 3. AG teknolojisi ile hazırlanmış materyallere yönelik öğrencilerin motivasyonları

\begin{tabular}{|l|c|c|}
\hline Faktörler & $\overline{\boldsymbol{X}}$ & Ss \\
\hline Dikkat Uygunluk & 4.60 & .45 \\
\hline Güven Tatmin & 4.55 & .56 \\
\hline Motivasyon Toplam & 4.64 & .42 \\
\hline
\end{tabular}

Sonuçlar incelendiğinde "dikkat uygunluk" alt boyutu ortalaması $4.60 \quad(\mathrm{Ss}=0.45)$. "güven tatmin" alt boyutunun ortalaması $4.55(\mathrm{Ss}=0.56)$ ve anketin genel ortalamasinın da $4.64(\mathrm{Ss}=0.42)$ olduğu görülmektedir. Elde edilen sonuçlar öğrencilerin arttırılmış gerçeklik teknolojisi ile hazırlanmış materyallere yönelik olarak öğrencilerin motivasyonlarının yüksek düzeyde olduğu görülmektedir.

Ögrencilerin AG uygulamalarına yönelik tutumları

İlköğretim 4. sınıf öğrencilerinin (AG) uygulamalarının kullanılmasına yönelik tutumlarına iliş̧kin bulgular ve faktör ortalamaları tablo 4'de sunulmuştur.

Tablo 4. (AG) uygulamalarının kullanılmasına yönelik tutumlarına ilişkin Faktör ortalamaları

\begin{tabular}{|l|c|c|}
\hline AG Tutum Faktörleri & N & Ortalama \\
\hline Faktör-1: AG uygulamalarına yönelik memnuniyet & 30 & 4.45 \\
\hline Faktör-2 AG uygulamalarının kullanılmasına yönelik kayg1 & 30 & 1.70 \\
\hline Faktör-3: AG uygulamalarını gelecekte kullanma isteği & 30 & 4.30 \\
\hline AG Uygulamaları Tutum Puanı & 30 & 3.48 \\
\hline
\end{tabular}

İlköğretim 4. sınıf öğrencilerinin AG uygulamalarının kullanılmasına yönelik tutumlarına ilişkin bulgular incelendiğinde öğrencilerin AG destekli öğretim uygulamalarına yönelik tutumlarının uygulama sonrası yüksek olduğu belirlenmiştir. Ölçekte yer alan maddeler incelendiğinde ise "AG uygulamalarıyla işlenen derslerden keyif alırım" içerikli maddenin \%93,3 oranda "kesinlikle katılıyorum" görüşü ile en yüksek puan ortalamasına sahip olduğu görülmüştür. Bunun yanında "AG uygulamaları ilgimi çekmez." İfadesini içeren faktör 2 maddesi $\% 70$ oranında bir değerle "kesinlikle katılmıyorum" görüşü ile en düşük puan ortalamasına sahip olduğu görülmüştür. Elde edilen sonuçlar AG uygulamalarına yönelik memnuniyet faktörü ortalaması 4.45 ve AG uygulamalarını gelecekte kullanma isteği faktörleri 4,30 puan ortalama değeri ile oldukça yüksek olduğu görülmüştür. Bunun yanında AG uygulamalarının kullanılmasına yönelik kaygı faktörü ortalama puanının 1.70 ile düşük olduğu belirlenmiştir. İki maddeyi içeren "AG uygulamalarını gelecekte kullanma isteği” faktörü için alınabilecek en yüksek ortalamaya oldukça yakın bir ortalama değer elde edilmiş olması öğrencilerin AR uygulamalarına derslerde yer verilmesi konusunda aynı düşüncede olduklarını göstermektedir. Ayrıca yedi maddeyi kapsayan "AG uygulamalarının kullanılmasına yönelik kaygı" faktörüne ait ortalamanın 1.70 gibi düşük çıkmış olması öğrencileri AG uygulamalarını kullanma konusunda kaygılı 
olmadıklarını göstermektedir. "AG uygulamalarına yönelik memnuniyet" faktörüne ilişkin 6 maddenin ortalamasının 4.45 elde edilmiş olması bu uygulamaya yönelik memnuniyetin yüksek olduğunu göstermektedir. AG Uygulamaları ortalama tutum puanı 3,48 olarak tespit edilmiştir. Bu sonuç yüksek tutum düzeyi ile uygulamaların sonuçlandığını göstermiştir.

Disiplinler arası kavram modeli temel alınarak bütünleştirilmiş ve AR materyalleri ile zenginleştirilmiş ögretim uygulamalarına yönelik öğrenci görüşleri

Gerçekleştirilen öğretim uygulamalarına yönelik olarak öğrencilerin yarı yapılandırılmış görüşme formu ile elde edilen görüşleri içerik analizine tabi tutulmuştur. Elde edilen sonuçlara ilişkin kod ve temalar Şekil 3'de sunulmuştur.
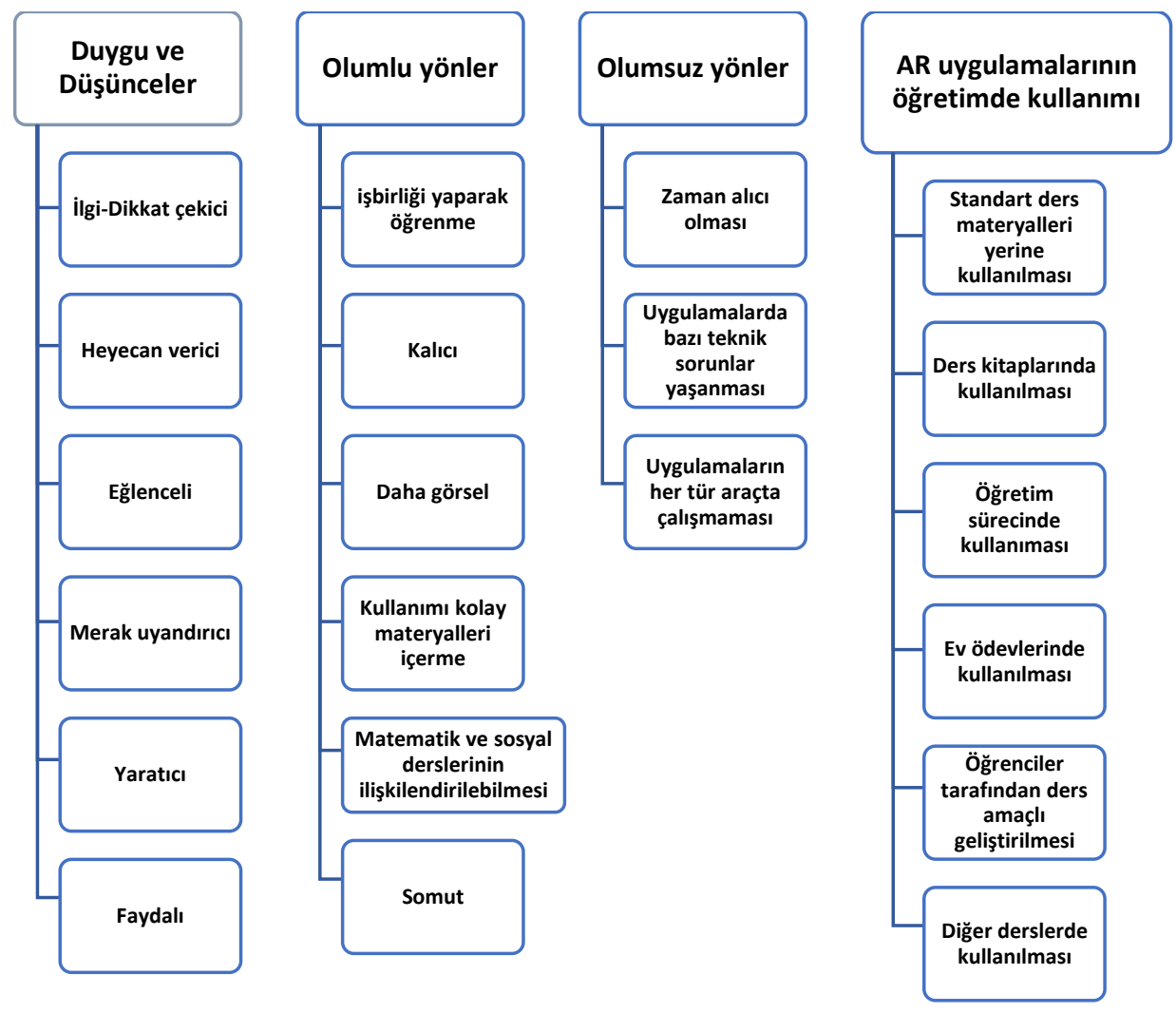

Şekil 3. Görüşlere ilişkin kod ve temalar

Şekil 3'de verilen elde edilen içerik analizi sonuçları incelendiğinde öğrencilerin disiplinler arası kavram modeli temel alınarak bütünleştirilmiş ve AR materyalleri ile zenginleştirilmiş öğretim uygulamalarını eğlenceli, merak uyandırıcı, yaratıcı, heyecan verici, faydalı, dikkat çekici buldukları görülmüştür. Buna göre duygu ve düşünceler temasında yer alan öğrenci görüşlerinden bazıları şöyledir.

Ö11: AG ile ilk karşılaştığımda inanamadım. Bunun bir yazılım olduğunu bilmiyordum. Gerçekten Harry Potter filmindeki gazeteler gibi canland sandım. Çok heyecan vericiydi. 
Ö7: Uygulamalar çok dikkatimi çekti. Normal derslerde bu kadar ilgi çekici şeyler yapmiyoruz. Uzayda gezmek gibiydi. Bir kitap okusaydım bu kadar ilgimi çekmezdi.

Ö8: Bence yaratıcılığımızı arttırdı. Başka başka dünyalara daldık. Hayal ettiğimiz şekilde düşünmeyi sağladl.

Ö2: Bence çok faydalı bir uygulama, kronolojik stralamayı ve sözlü tarihi birlikte ögrendik. Bunu yaparken AG uygulamaları çok faydalı oldu. Çünkü daha ilgi çekiciydi.

Bunun yanında AG uygulamalarının her cihazda çalışmaması araştırmacılar tarafindan öğrenme ortamına uygun android cihazlar getirerek uygulamaların gerçekleştirilmesi öğrenciler açısından olumsuz yönler olarak görülmüştür. İlgili temada öğrencilerden az bir kısmı uygulamayı zaman alıcı bulmuş, her cihazda çalışmamasını dezavantaj olarak görmüştür.

Gerçekleştirilen disiplinler arası AG destekli öğretim uygulamalarına ilişkin olarak öğrenciler iş birliği yaparak öğrenme firsatı vermesi, kalıc1, daha görsel, matematik ve sosyal derslerinin ilişkilendirilebilmesi ve AG materyallerinin kolay kullanılması konularında olumlu görüşler bildirmişlerdir. Uygulamaya ilişkin olumlu yönler temasında yer alan öğrenci görüşlerinden bazıları şöyledir.

Ö4: Birlikte iş birliği yaparak öğrenmemizi sağladı. Beraber yeni bir poster ürettik, bilgimizi paylaşarak ögrendik.

Ö 12: Bu şekilde ögrrenmek çok kalıcı oldu. Diğer dersleri çabuk unutuyorum. Bu deneyimi unutmam çok zor.

Ö19: Önce Disney'in hayatını inceliyoruz, sosyal bilgiler dersi yapıyoruz zannettim. Ama sonra kendimi matematikle ilgili zaman hesapları yaparken buldum. Hiçbir şeyi ögretmen anlatmadı biz sorularl cevaplarken ögrrendik. Sosyal ve matematik dersi birleşti çok eğlenceliydi.

AG uygulamalarının öğretimde kullanılmasına ilişkin tema incelendiğinde öğrencilerin AG uygulamalarının standart ders materyalleri yerine kullanılmasını, ders kitaplarında kullanılmasını, öğretim sürecinde kullanılmasını, ev ödevlerinde kullanılması, diğer derslerde kullanılması ya da öğrenciler tarafindan ders amaçlı geliştirilmesini istedikleri belirlenmiştir. Bu temaya iliş̧in öğrenci ifadelerinde bazıları şöyledir.

Ö7: Öğretmenimiz sizin gibi diğer derslerde de kullanmalı AG uygulamalarını bence. Çünkü teknoloji çok gelişmiş biz gerideymişiz gibi ders işliyoruz. Çok sıkıcı

Ö19: Bence bizde yapabiliriz. Ödevlerimi AG kullanarak yapmayı ve arkadaşlarımı şaşırtmay isterdim. Ben mühendis olmak istiyorum. O yüzden bende bu teknolojiyi kullanmak istiyorum.

Ö22: Bence ögretmenlerin verdiği ödevlerde farkl olmall. Eve gidince ödev canlansa ya da çözdüğüm soruların çözümlerini hemen görsek yani dersi beklemesek daha kalıcı olurdu. 
Ö 29: Bence okulda kullandığımız diğer materyaller yerine kullanabiliriz. Çünkü resimler anlaşılmıyor. AG uygulamaları canlanıyor. Bu materyaller kullanılsa daha çok ilgimizi çeker. Mesela ayın hareketlerini resimlerden değil de canlanan bir ay görüntüsünden daha iyi anlardım.

Bunun yanında öğrencilerin benzer şekilde derslerin ilişkilendirilmesini ve AG uygulamalarıyla desteklenmesini istedikleri belirlenmişti. Örnek öğrenci görüşleri şöyledir.

Ö3: Fen derslerinde değişik konular ve gezegenler ay gök cisimlerinde kullanılsın. Canlanırlarsa çok güzel olurdu.

Ö8: Trafik derslerinde kuralları ögrenirken kullanılsın, kitaplar canlansın ve taşıtlar seyahat etsin. O zaman daha iyi ögrenirdik.

Ö11: Matematik derslerinde üç boyutlu cisimlerle ilgili materyallerde kullansak ve içinde dolaşsak çok güzel olurdu. Belki bir küpü gezerken ayın hareketlerini izlesem ikisini aynı anda öğrenirdim. Fen derslerinde anlaşılmayan çok konu ve görsel var kitaplarda kullanılsa çok faydalı olurdu

Ö2: Müzik dersinde notaları ögrenirken o notaların piyanodaki çalınışı AG ile dışarı çıksa çok güzel olurdu.

\section{Sonuç ve öneriler}

AG, öğrencilerin daha fazla duyu organına hitap ederek öğrenme öğretme sürecinde öğrenci anlayışının artmasına yardımcı olan bir teknolojidir. AG etkinlikleri öğrenme ve öğretim sürecinde, öğrencilerin soyut kavramları anlamalarına yardımcı olduğu gibi bilgi paylaşımı yapabilme imkânı sağlamaktadır. Ayrıca kullanıcıların sanal nesnelerle, gerçek ortamda eş zamanlı etkileşim kurarak, gerçek dünya ortamı ve sanal nesnelerle doğal etkileşim kurabilmesini sağlar. Artırılmış gerçekliğin eğitim ortamlarındaki uygulamalarına ilişkin yapılan çalışmalar incelendiğinde; AG kullanımının öğrencilerin ilgi ve dikkatlerini derse çekmede etkili olduğu ve tutumlarını olumlu şekilde arttırdı̆̆ 1 [22], öğrencilerin derse karşı olan motivasyonlarını artırdığı, soyut kavramları somutlaştırarak öğrenmeyi kolaylaştırdığı [31], yaparak ve yaşayarak öğrenmeyi desteklediği [71], sonuçlarına ulaşılmıştır. Yapılan bu uygulamada ise öğrenciler yaparak yaşayarak öğrenme imkânı bulmuş ve disiplinler arası bir ortamda AG teknolojisinin öğrenme ortamına entegresi üzerine örnek bir model geliştirilmiştir. $\mathrm{Bu}$ kapsamda Matematiksel terimlerin, kavramların ve becerilerin günlük yaşama gerçekçi ve pratik biçimde uygulanmasının birleştirildiği bir yapıya sahip olan Sosyal bilimler ile matematik disiplinini yeni bir teknoloji olan AG yi kullanarak bütünleştirmeyi amaçlayan bu çalışma yenilikçi eğitim ortamlarına ilişkin örnek bir uygulama niteliğindedir. Disiplinler arası perspektif ile AG teknolojisini ilk kez bütünleştiren bu çalışma ile öğrencilerin hem matematik hem sosyal bilgiler dersi akademik başarılarını arttırdığ 1 sonucuna ulaşılmıştır. Elde edilen sonuçlar öğrencilerin arttırılmış gerçeklik teknolojisi ile hazırlanmış materyallere yönelik olarak öğrencilerin motivasyonlarının yüksek düzeyde olduğu belirlenmiştir.

Yapılan uygulama ile öğrencilere zor gelen ay-yıl-gün hesabı ve kronolojik sıralama kavramı günlük yaşam problemlerinin yer verildiği AG üst materyalleri ile dikkat çekici 
hale gelerek öğrenilme düzeyi pozitif yönde etkilemiştir. Eğitimde AG uygulamaları öğrenme sürecinde öğrencilere önemli kazanımlar sağlamaktadır [71-74]. AG uygulamalarının öğrenme sürecinde olumlu etkiler oluşturmasında öğrencilerin bu tür uygulamalara yönelik tutumları ve görüşleri önemli bir faktör olarak ortaya çıkmaktadır. Çalışmada öğrencilerin pek çoğunun AG uygulamalarına yönelik tutum ve görüşlerinin olumlu olduğu, diğer derslerde, materyal ve kitaplarda kullanılmasını istedikleri, AG gibi mobil uygulamalar ve yenilikçi teknolojilerin derslerde kullanılmasına ilgi duydukları belirlenmiştir.

2011-2015 yılları arasında yayınlanan 495 lisans üstü tez çalışması incelendiğinde yenilikçi teknolojilerin (hareketle öğrenme, artırılmış ve sanal gerçeklik uygulamaları, giyilebilir teknolojiler) eğitim ortamlarında kullanılmasına yönelik sadece 7 tez bulunduğu görülmektedir [75]. Çalışma sonuçları hareket temelli öğrenme, AG, sanal gerçeklik ve giyilebilir teknolojiler gibi yenilikçi teknolojilerin eğitimde etkilerini araştıran yeterli sayıda çalışmanın olmadığını belirlenmiştir. Yapılan çalışmaların ise tek bir disipline dayalı olarak tasarlanması söz konusudur.

$\mathrm{Bu}$ kapsamda yenilikçi teknolojilerin eğitim üzerindeki etkilerinin daha iyi anlaşılabilmesi için daha fazla çalışmaya ihtiyaç olduğu düşünülmektedir. Bu bağlamda daha fazla disiplinler arası perspektife dayalı olarak AG destekli materyaller geliştirilmesi, öğretmen eğitimi açısından faydalı ve yenilikçi bir öğretim içeriğinin ve materyallerinin literatüre kazandırılması, farklı teknolojilerinde bu perspektifle disiplinler arası öğrenme ortamlarına entegre edilerek etkilerinin incelenmesi gelecekteki çalışmalar için önerilmektedir. Eğitimde AG uygulamaları öğrenme sürecinde öğrencilere önemli kazanımlar sağlamaktadır [72-74,78]. AG uygulamalarının öğrenme sürecinde olumlu etkiler oluşturmasında öğrencilerin bu tür uygulamalara yönelik motivasyonları tutumları ve görüşleri önemli bir faktör olarak ortaya çıkmaktadır. $\mathrm{Bu}$ doğrultuda gelecekte farklı disiplinlerin entegrasyonu ile gerçekleştirilen AG uygulamalarının öğrencilerin tutum ve görüşlerine akademik başarı ve motivasyonlarına etkisinin incelenmesi ve öğrencilerin talebi doğrultusunda mevcut ders materyallerinin AG uygulamaları ile zenginleştirilmesi önerilmektedir.

\section{Teşekkür}

$\mathrm{Bu}$ çalışma Balıkesir Üniversitesi Bilimsel Araştırma Projeleri Birimi tarafından desteklenen 2018/005 nolu araştırma projesinin bir bölümünü içermektedir.

\section{Kaynaklar}

[1] Niess, M. L., Investigating TPACK: Knowledge growth in teaching with technology. Journal of Educational Computing Research, 44(3), 299-317, (2011).

[2] ISTE, International Society for Technology in Education. Global reach of the ISTE Standards. http://www.iste.org/standards/standards-in-action/globalreach, (2017).

[3] UNESCO, 'Manual for Pilot Testing the Use of Indicators to Assess Impact of ICT Use in Education.' http://www.unescobkk.org/education/ict/resource, (2003). 
[4] Hew, K. F. ve Brush, T., Integrating technology into K-12 teaching and learning: Current knowledge gaps and recommendations for future research. Educational Technology Research and Development, 55(3), 223-252, (2007).

[5] Cuban, L., Kirkpatrick, H., ve Peck, C., High access and low use of technologies in high school classrooms: Explaining an apparent paradox. American Educational Research Journal, 38(4), 813-834, (2001).

[6] NCES, National Center for Educational Statistics, Internet access in U.S. public schools and classrooms: 1994-2001. Online report. Retrieved from: http://nces.ed.gov/pubs2002/internet/4.aspGoogle Scholar, (2002)

[7] Bingimlas, K. A., Barriers to the successful integration of ICT in teaching and learning environments: A review of the literature. Eurasia Journal of Mathematics, Science and Technology Education, 5(3), 235-245, (2009).

[8] Karaseva, A., Pruulmann-Vengerfeldt, P. ve Siibak, A Comparison of different subject cultures and pedagogical use of ICTs in Estonian schools. Nordic Journal of Digital Literacy, 8(03), 157-171, (2013).

[9] Wang, Q. A, generic model for guiding the integration of ICT into teaching and learning. Innovations in Education and Teaching İnternational, 45(4), 411419., (2008).

[10] Radu, I., Augmented reality in education: a meta-review and cross-media analysis. Personal and Ubiquitous Computing, 18(6), 1533-1543., (2014).

[11] Sivri, Ş. N., ve Arı, A. G., Genel biyoloji dersine yönelik ag teknolojisi ile mobil uygulama tasarımı ve öğrenci görüşlerinin incelenmesi. Eğitim Teknolojisi Kuram ve Uygulama, 10(1), 257-279., (2015).

[12] Azuma, R. T. A survey of augmented reality. Presence: Teleoperators ve Virtual Environments, 6(4), 355-385, (1997).

[13] Johnson, L., Levine, A., Smith, R., ve Stone, S., Simple augmented reality. The 2010 Horizon Report, 21-24. Austin, TX: The New Media Consortium, (2010).

[14] Lee, K.,Augmented reality in education and training. TechTrends, 56(2), 1321., (2012).

[15] Sırakaya, D. A., Ters yüz sınıf modelinin akademik başarı, öz-yönetimli öğrenme hazırbulunuşluğu ve motivasyon üzerine etkisi. Yayınlanmamış Doktora tezi, Gazi Üniversitesi, Eğitim Bilimleri Enstitüsü, Ankara. (2015).

[16] Wojciechowski, R., ve Cellary, W., Evaluation of learners' attitude toward learning in ARIES augmented reality environments. Computers and Education, 68, 570-585., (2013).

[17] Sirakaya, M., ve Alsancak Sirakaya, D., Trends in Educational Augmented Reality Studies: A Systematic Review. Malaysian Online Journal of Educational Technology, 6(2), 60-74, (2018).

[18] Hwang, G. J., Wu, P. H., Chen, C. C., ve Tu, N. T., Effects of an augmented reality-based educational game on students' learning achievements and attitudes in real-world observations. Interactive Learning Environments, 24(8), 18951906., (2016).

[19] Zhang, J., Sung, Y. T., Hou, H. T. ve Chang, K. E., The development and evaluation of an augmented reality-based armillary sphere for astronomical observation instruction. Computers and Education, 73, 178-188, (2014).

[20] Olsson, T., ve Salo, M., Online user survey on current mobile augmented reality applications. In Mixed and augmented reality (ISMAR), 2011 10th IEEE international symposium, (pp. 75-84). IEEE (2011). 
[21] Perez-Lopez, D., ve Contero, M., Delivering educational multimedia contents through an augmented reality application: A case study on its impact on knowledge acquisition and retention. TOJET: The Turkish Online Journal of Educational Technology, 12,4,19-28. (2013).

[22] Delello, J. A., Insights from pre-service teachers using science-based augmented reality. Journal of Computers in Education, 1(4), 295-311., (2014).

[23] O'Brien, H. L., ve Toms, E. G., What is user engagement? A conceptual framework for defining user engagement with technology. Journal of the American society for Information Science and Technology, 59(6), 938-955. (2008).

[24] Ab Aziz, K., Ab Aziz, N. A., Yusof, A. M., ve Paul, A. Potential for providing augmented reality elements in special education via cloud computing. Procedia Engineering, 41, 333-339. (2012).

[25] Ersoy, H., Duman, E., ve Öncü S., AG ile Motivasyon ve Başarı: Deneysel Bir Çalışma. Journal of Instructional Technologies and Teacher Education, 5(1)., (2016).

[26] Singhal, S., Bagga, S., Goyal, P., ve Saxena, V., Augmented chemistry: Interactive education system. International Journal of Computer Applications, 49 (15), 1-5., (2012).

[27] Di Serio, Á ., Ibáñez, M. B., ve Kloos, C. D., Impact of an augmented reality system on students' motivation for a visual art course. Computers \& Education, 68, 586-596. doi:10.1016/j.compedu. (2013).

[28] Baysan, E., ve Uluyol, Ç., Arttırılmış Gerçeklik Kitabının (AG-KİTAP) Öğrencilerin Akademik Başarılarına Etkisi ve Eğitim Ortamlarında Kullanımı Hakkında Öğrenci Görüşleri. Eğitim ve İnsani Bilimler Dergisi: Teori ve Uygulama, 7(14), 55-78., (2016).

[29] Chen, C. P., ve Wang, C. H., Employing augmented-reality-embedded instruction to disperse the imparities of individual differences in earth science learning. Journal of Science Education and Technology, 24(6), 835-847. (2015).

[30] Hsiao, K. F., Chen, N. S. ve Huang, S. Y., Learning while exercising for science education in augmented reality among adolescents. Interactive learning environments, 20(4), 331-349., (2012).

[31] Cai, S., Wang, X. ve Chiang, F. K., A case study of Augmented Reality simulation system application in a chemistry course. Computers in Human Behavior, 37, 31-40, (2014).

[32] Shelton, B. E., ve Hedley, N. R., Using augmented reality for teaching earth-sun relationships to undergraduate geography students. In The First IEEE International Workshop Agumented Reality Toolkit, IEEE. (2002)

[33] Shelton, B. E., ve Stevens, R., Using coordination classes to interpret conceptual change in astronomical thinking. Proceedings of the 6th international conference for the learning sciences. Lawrence Erlbaum ve Associates, Mahweh, NJ. (2004).

[34] Bujak, K. R., Radu, I., Catrambone, R., MacIntyre, B., Zheng, R., ve Golubski, G. A psychological perspective on augmented reality in the mathematics classroom. Computers \& Education, 68, 536-544., (2013).

[35] Rosenbaum, E., Klopfer, E. Boughner, B. ve Rosenheck, L. Engaging students in science controversy through an augmented reality role-playing game," in Proc. of CSCL, pp. 608-610., (2007) 
[36] Sharples, M., Mobile learning: small devices, big issues. In N. Balacheff, Ludvigsen, S., T. Jong de ve S. Barnes (Eds.), Technology Enhanced Learning: Principles and Products. (pp. 233-249), Heidelberg, Germany: Springer., (2009).

[37] Tomi, A. B., ve Rambli, D. R. A. An interactive mobile augmented reality magical playbook: Learning number with the thirsty crow. Procedia computer science, 25, 123-130., (2013).

[38] Taşkıran, A., Koral, E., ve Bozkurt, A., Arttırılmış gerçeklik uygulamasının yabancı dil öğretiminde kullanılması. Akademik Bilişim Kongresi, (2015).

[39] Zarzuela, M. M., Pernas, F. J. D., Martínez, L. B., Ortega, D. G., ve Rodríguez, M. A. Mobile serious game using augmented reality for supporting children's learning about animals. Procedia computer science, 25(Supplement C), 375381., (2013).

[40] Timur, B., ve Özdemir, M., Fen Eğitiminde Artırılmış Gerçeklik Ortamlarının Kullanımına İlişkin Öğretmen Görüşleri. Uluslararası Türk Eğitim Bilimleri Dergisi, 2018(10), 62-75. (2018).

[41] Dunleavy, M., Dede, C., ve Mitchell, R., Affordances and limitations of immersive participatory augmented reality simulations for teaching and learning. Journal of Science Education and Technology, 18, 7-22. doi:10.1007/s10956008 9119-1 (2009).

[42] Liu, W., Cheok, A. D., Mei-Ling, C. L., ve Theng, Y. L., Mixed reality classroom: learning from entertainment. In Proceedings of the 2nd international conference on Digital interactive media in entertainment and arts (pp. 65-72). ACM., (2007).

[43] Lu, S. J., ve Liu, Y. C., Integrating augmented reality technology to enhance children's learning in marine education. Environmental Education Research, 21(4), 525-541, (2015).

[44] Schrier, K., Using augmented reality games to teach 21 st century skills. Paper presented at the ACM Siggraph 2006 Conference, Boston, (2006).

[45] Squire, K. ve Jan, M. Mad city mystery: Developing scientific argumentation skills with a place-based augmented reality game on handheld computers.

Journal of Science Education and Technology, 16(1), 5-29, (2007).

[46] Kaufmann, H., Steinbügl, K., Dünser, A., ve Glück, J. General training of spatial abilities by geometry education in augmented reality. Annual Review of CyberTherapy and Telemedicine: A Decade of VR, 3, 65-76, (2005).

[47] Lin, T. J., Duh, H., Li, N., Wang, H. Y., ve Tsai, C. C. An investigation of learners' collaborative knowledge construction performances and behavior patterns in an augmented reality simulation system. Computers \& Education, 68, 314-321, (2013).

[48] Ferrer-Torregrosa, J., Torralba, J., Jimenez, M. A., García, S. ve Barcia, J. M. ARBOOK: Development and assessment of a tool based on augmented reality for anatomy. Journal of Science Education and Technology, 24(1), 119-124, (2015).

[49] Ibanez, M., Kloos, C., Leony, D., Rueda, J., ve Maroto, D., Learning a foreign language in a mixed- reality environment, Internet Computering IEEE, 15, 6, 44-47. (2011).

[50] Mahadzir, N. ve Phung, L. The use of augmented reality pop-up book to increase motivation in English language learning for national primary school. Journal of Research \& Method in Education, (1) 1, 26-38, (2013). 
[51] Bacca, J., Baldiris, S., Fabregat, R., Graf, S., ve Kinshuk. Augmented Reality Trends in Education: A Systematic Review of Research and Applications. Journal of Educational Technology \& Society, 17(4), 133-149. (2014).

[52] Keller, J. M., ve Litchfield, B. C. Motivation and performance. Trends and issues in instructional design and technology, 2, 89-92. (2002).

[53] Theall, M. Motivation from within: Approaches for encouraging faculty and students to excel, New Directions for Teaching and Learning (1999)

[54] Keller, J. M. Motivational design of Instruction. In C. M. Reigeluth (Ed.), Instructional Design Theories and Models . Hillsdale, NJ: Lawrence Erlbaum Associates. (1983).

[55] Keller, J. M. Strategies for stimulating the motivation to learn. Performance and instruction, 26(8), 1-7. (1987).

[56] Keller, J. M. Challenges in learner motivation: A holistic, integrative model for research and design on learner motivation. In The 11th International Conference on Education Research. (2010).

[57] Creswell, J. W. Araştırma deseni: Nitel, nicel ve karma yöntem yaklaşımları (S. B. Demir, çev). Ankara: Eğiten Kitap. (2014).

[58] Balc1, A., Sosyal Bilimlerde Araştırma Yöntem, Teknik ve İlkeler. Bask1, Ankara: Pagem Yayıncilık. (2005).

[59] Karasar, N. Bilimsel Araştırma Yöntemi Ankara: Nobel Tıp Kitabevleri Ltd. (2008).

[60] Creswell, J. W. Research design: Qualitative and quantitative approaches. Thousand Oaks, 88(2), 207. (2012).

[61] Yıldırım, A. ve Şimşek, H. Sosyal Bilimlerde Nitel Araştırma Yöntemleri. Ankara: Seçkin Yayıncılık. (2013).

[62] Kutu, H. ve Sözbilir, M. Öğretim materyalleri motivasyon anketinin Türkçeye uyarlanması: Güvenirlik ve geçerlik çalışması. Necatibey Eğitim Fakültesi Elektronik Fen ve Matematik Ĕgitimi Dergisi, 5(1), 292-312. (2011).

[63] Küçük, S., Y1lmaz, R., ve Göktaş, Y. İngilizce öğreniminde AG: Öğrencilerin başarı, tutum ve bilişsel yük düzeyleri. Eğitim ve Bilim, 39(176). (2014).

[64] Tavşancıl, E. ve Aslan, E. Sözel, Yazılı ve Diğer Materyaller için İçerik Analizi ve Uygulama Örnekleri. Epsilon Yayınevi, İstanbul. (2001).

[65] Miles, M. B., ve Huberman, A. M. Qualitative data analysis: An expanded source book (2nd ed.). Thousand Oaks, CA: Sage. (1994).

[66] Jacobs, H. H., ve Borland, J. H. The interdisciplinary concept model: Theory and practice. Gifted Child Quarterly, 30(4), 159-163. (1986).

[67] Jacobs, H. H. Interdisciplinary curriculum: Design and implementation. Association for Supervision and Curriculum Development, 1250 N. Pitt Street, Alexandria, VA 22314. (1989).

[68] Lattuca, L. R. Creating interdisciplinarity: Interdisciplinary research and teaching among college and university faculty. Vanderbilt university press.

[69] Rosenfield, P. L. (1992). The potential of transdisciplinary research for sustaining and extending linkages between the health and social sciences. Social science \& medicine, 35(11), 1343-1357. (2001).

[70] Yıldırım, A. Disiplinlerarası öğretim kavramı ve programlar açısından doğurduğu sonuçlar. Hacettepe Üniversitesi Eğitim Fakültesi Dergisi, 12(12). (1996).

[71] Wu, H. K., Lee, S. W. Y., Chang, H. Y., ve Liang, J. C. Current status, opportunities and challenges of augmented reality in education. Computers \& Education, 62, 41-49. (2013). 
[72] Farias, L. ve Dantas, R.R., Educ-AR: A tool for assist the creation of augmented reality content for education. IEEE International Conference on Virtual Environments, HumanComputer Interfaces and Measurement Systems, 1921. (2011).

[73] Kaufmann, H. ve Papp, M. Learning objects for education with augmented reality. Proceedings of European Distance and E-Learning Network Conference, 160-165. (2006).

[74] Oh, S. ve Woo, W. ARGarden: Augmented edutainment system with a learning companion. Transactions on Edutainment I Lecture Notes in Computer Science Volume 5080, 40-50. (2008).

[75] Çalışkan, E. Examination of Turkish master theses and doctoral dissertations in terms of using innovative technologies in education among 2011-2015 Eğitimde yenilikçi teknolojilerin kullanımı açısından Türkiye'de son beş yıl içerisinde (2011-2015) tamamlanmış lisansüstü tezlerin incelenmesi. Journal of Human Sciences, 14(1), 496-505. (2017).

[76] İzgi Onbaşılı, Ü. Artırılmış gerçeklik uygulamalarının ilkokul öğrencilerinin artırılmış gerçeklik uygulamalarına yönelik tutumlarına ve fen motivasyonlarına etkisi. Ege Ĕgitim Dergisi, 19(1), 320-337. (2018).

[77] Azı, F. B. Artırılmış gerçeklik uygulamalarının sosyal bilgiler dersinde akademik başarı ve ders tutumlarına etkisi. Yayınlanmamış Yüksek Lisans Tezi. Necmettin Erbakan Üniversitesi, Eğitim Bilimleri Enstitüsü Bilgisayar ve Öğretim Teknolojileri Eğitimi Anabilim Dalı, Konya.(2020).

[78] Seyhan, A., ve Küçük, S. Sosyal Bilgiler Öğretmenleri ve Öğretmen Adaylarının Eğitsel Artırılmış Gerçeklik Uygulaması Geliştirme Deneyimleri. Journal of Higher Education \& Science/Yüksekögretim ve Bilim Dergisi, 11(1), 56-63. (2021). 